\title{
ET VIRTUTEM ET MUSAS: MILL HILL SCHOOL AND THE GREAT WAR
}

\author{
by CLYDE BINFIELD
}

\section{'I}

T IS the duty of every Christian man to regard his religion as the Expeditionary Force of his soul'.1

In the autumn of $1950 \mathrm{~W} . \mathrm{H}$. Balgarnie, a retired public school-master, was asked to reminisce about his early days in the profession. Balgarnie's boys certainly remembered him, 'very young-looking for his age, so much so that on one occasion we were rejoiced by a parent approaching him on the touch-line of the football field and saying: "Can you tell me where Mr. Balgarnie is, my boy?"'2 Balgarnie replied from his house in Cambridge:

... I came in 1890 , and stayed only $3 \frac{1}{2}$ years, and know nothing of the great Eltham days. 'S.S.M.' was our abbreviation for 'School for the Sons of Missionaries', wh. I suppose was held not terse enough for a slogan on the football field. The School was quite small in my time, and 50 was accounted a full house. The Rev. Edward Waite was Headmaster-a beautiful reader of the Psalms at morning prayers - and I was under Mr. Hayward for only a year: it was he who took the motto from the Apocrypha, Filiorum gloria Patres.

I came to The Leys in 1900 , and left 3 or 4 times, but always had to return: now I've finally left (memini tangere lignum), and live opposite the School, like Mr. Chips, with whom I've been fancifully identified. ${ }^{3}$

The identification was not so fanciful, nor was Mr. Chips, even at one remove, Eltham College's only link with middle-brow novels and family cinema. From 1908 to 1919 Eric Liddell, rugby international, Olympic athlete, China missionary and a hero of 'Chariots of Fire' was at the school, two incidents of his sporting after life reclaimed for The Glory of the Sons. One of them, 'perhaps

1 [The] $M[i l l] H[i l l] M[$ agazine $]$, June 1922 p 6.

2 [The] Glory of the Sons [A History of Eltham College School for the Sons of Missionaries]ed. C. Witting (London 1952) p 164.

3 Ibid p 39; W. H. Balgarnie to C. Witting, 6 Brookside, Cambridge, 26 August 1950. 
unique in the history of rugger took place at Cardiff on 3rd February 1923, when, Scotland having beaten Wales by 11 to 8 , the Scottish threes, Liddell and Gracie among them, were carried off the field by the Welsh as a compliment to their magnificent game'. The other occurred at the 1924 Paris Olympics when, running 'with an inspired and passionate intensity', Liddell first set a world record for the four hundred metres and then refused, on conscientious grounds, to run the hundred metres heats on a Sunday. 'That act, by which he brought an even greater honour to his old school, will perhaps be held in more enduring memory than the fact that he set up a world record.'4

No doubt much might be drawn from this introductory collage about sport, school spirit and public school religion, flies caught together in the brittle amber of a privileged little world. But two things should be noted. The first is that this public school collage is in fact of a Free Church school world. The Leys, opened in Cambridge in February 1875, was a Wesleyan school; Eltham College, opened in Walthamstow in January 1842 was for the sons of missionaries, chiefly Congregational and Baptist. When Balgarnie knew it, it was at Blackheath; since 1912 it has been at Mottingham, hence its present name, Eltham College. The second point is that Gracie and Liddell, those glories of public school boyhood, moved with their school from Blackheath to its new name, its new charter, and the experience of war. Gracie, who bowled W. G. Grace when he brought a team to Eltham in 1914, won every event in his last school sports. That was in 1915. Two years later came his military cross ${ }^{5}$. Liddell stayed at Eltham throughout the war. Like his father and younger brother he was destined for missionary work in China ('When he left for China, he had a tremendous send-off from the Edinburgh students at Waverley Station, singing the hymn, "Jesus shall reign where'er the sun" "). ${ }^{6}$ His war was to be the second world war, with death in Japanese internment.

To return to Mr. Chips, retired by 1950 at Brookside, a row, almost a terrace, of variably Victorian, invariably donnish Cambridge houses, which were none of them what they seemed,

4 lbid $\mathrm{p} 77$.

5 Ibid pp $270,278$.

- Ibid $\mathrm{p} 155$. 


\section{Et Virtutem Et Musas}

for they looked across Trumpington Road to the Methodist Leys School while packed behind them since its opening in October 1915 was Cheshunt, the dissenting theological college originally established at Trevecca by Lady Huntingdon. In 1944 Cheshunt's president, J. S. Whale, left to become headmaster of the best known of the Free Church schools, Mill Hill.

An interconnexion might easily be made of Free Church parents, preachers, teachers and fellows, an ivy league threaded among the Cambridge colleges. But would there be any distinctiveness about such an interconnexion? And would there be much significance in isolating such threads as happened to lie in times of war?

James Obelkevich, sensitively parti pris in his study of Lincolnshire religion, has savaged that contradiction in terms, the Christian gentleman 7 . More recently Dennis Smith, less sensitive, still suggestive, has considered the education, public school pioneered and grammar school undergirded, which prolonged the Christian gentleman's life and broadened its social range ${ }^{8}$. It was a liberal education in which gentlemen and professional men, Christians all and all-round chaps, might coincide, here a City businessman, there a Fabian socialist, a socially integrated old boy network of commercial and political pacesetters, fundamentally incompatible no doubt, but sharing a lingua franca, united in a distrust of technical specialisms, distanced from, indeed denying, the industrial civilisation which provided their wealth. So where stood the Methodist schools, the Quaker schools, the schools for sons of ministers and missionaries, the Tauntons and Tettenhalls, Bishop's Stortfords and Mill Hills in this integration of incompatibles? Where, especially, stood one of them, Mill Hill, when the Christian gentleman faced the ultimate test, fighting for king and country, and when its own purpose had been the selective assimilation to national standards of boys for whose families war had perhaps been a distant option but never a personal obligation?

On 18 June 1845 Algernon Wells, secretary of the Congregational Union, spoke at Mill Hill's Public Day. The man fitted the occasion. Wells was one of a group of leading Congregational-

7 J. Obelkevich, Religion and Rural Society: South Lindsey 1825-1875 (Oxford 1976) pp 44-6.

8 [D. Smith], Conflict and Compromise: [Class Formation in English Society 1830-1914: A Comparative Study of Birmingham and Sheffield] (London 1982) pP 252-5. 
ists-Robert Vaughan of Lancashire Independent College, Manchester, and Thomas Binney of the King's Weigh House Church, London, were others-convinced of their denomination's formative role in the new age of great cities. Theirs was the social pivot on which the national future balanced. The Protestant Dissenters' Grammar School, founded at Mill Hill in 1807, shared its architect, Sir William Tite, with the Scotch National Church in Regent Square, Binney's Weigh House chapel in Fish Street Hill, a string of railway stations, some banks and the Royal Exchange. Each was an earnest of the future, none was as suggestive as the school: the 'improved training of the sons of intelligent Dissenting families, with a view to their acting a worthy part, on high moral and religious principles, in the great intellectual struggle of our own and coming times, is an object the importance of which can be hardly overrated'. 9

So Wells spoke at Public Day, his theme the school, his audience its whole constituency, 'scholars and parents, tutors, committee, former pupils, and governors', the occasion 'one of the bright days of life given to pleasure, affection, and hope', the content predictably measured. ${ }^{10} \mathrm{He}$ spoke of a school that was grammar, public and Christian. Wells spoke for a grammar school since the study of language is, 'next to reason itself, perhaps the noblest and most curious work of God in our world . . . he who has become a master of sentences is prepared for every department of study, he is disciplined for the intellectual life. '11 $\mathrm{He}$ dwelt upon the perfection of the classics, ('Let the Bible be used to teach religion only, at least to youth'), and since 'Mill Hill is no scene of negligence, or indolence' he stressed that 'Mathematics are diligently taught. The usual requisites to a mercantile education receive due attention. Modern languages take their place. Occasional lectures on science are given. '12 But Wells spoke too for a public school. 'It is public property, is under public care, is established for public objects ... [is] instituted to promote an effective rudimental education in the higher walks of literature, by

\footnotetext{
9 A. Wells, An Address Delivered in the Chapel of the The Protestant Dissenters' Grammar School, Mill Hill, On Occasion of Public Day, June 18th, 1845 p 2.

10 Ibid $\mathrm{p} 3$.

$"$ Ibid pp 4, 5: Sir James Murray, the lexicographer, was a master at Mill Hill from 1870 to 1885 .

12 Ibid p 6.
} 


\section{Et Virtutem Et Musas}

public and combined efforts. ${ }^{13}$ His imagination played with his oratory upon the thought. A public school was a good sized school, a 'secluded, but real and active commonwealth', ${ }^{14}$ providing what no family 'in that class of society from which the pupils of Mill Hill are gathered' could provide:

There are rules, laws, and hours that must be kept. Needful discipline is maintained, Salutary fear is established. Boys feel that they are governed. ... In such institutions boys can play. They find playfellows and playroom. They can obtain a resolute trial of strength and skill ... nerves are braced, senses are exercised, limbs are strengthened, tone is gained for life amidst the strenuous games of free and gladsome boys breaking forth from school application into the open air and scenes of nature . . But there is another great good in the plays of boys. In them equals meet equals. Courtesy and disguise are equally out of the question. Rights are maintained, and offences are punished with prompt decision. There is a code of laws and a standard of conduct, which are summarily enforced. The play field is indeed but mimic and miniature life, but still it is social life. It schools lads in the art of meeting and acting among their fellows in the real world they are soon to enter. Here conceit is humbled, mean tricks are scorned, unfair advantage-taking is repelled, arrogant assumptions are brought down, and a lad is made to feel that he must be frank and honourable among his fellows, and respect their rights, or be thrust out of their society.

In other words he is disciplined for future life. ${ }^{15}$

Or, to put it another way, 'the good schoolboy, subject to his master, diligent in his class, spirited among his fellows, makes the true man, prompt in business, kind at home, pleasant in society, and firm in troubles'; and thus the good school's principal care must be to 'cherish a right tone of social feeling among the pupils as a community'. ${ }^{16}$ Wells wanted more yet, for he spied a comunity in perpetuity. Mill Hill 'should be the school of successive generations', the son at work and play 'where his father studied and frolicked before him'. ${ }^{17}$ And here, almost lost in the charm and

13 Ibid p 10.

14 Ibid.

15 Ibid pp 8-9.

16 Ibid $\mathrm{p} 10$.

17 Ibid pp 11-12. 
interest of lengthened associations ("after all there may one day be a Dissenting institution covered with the hoar and the moss of antiquity'), Algernon Wells came up against the fact of dissenting dissidence and the need for schools where the fathers of our faith and liberty will never be mentioned but with reverence, and where simple worship, free thought, and personal responsibility in religion, shall make their constant appeals to opening reason and impressible conscience'. ${ }^{18}$

So of course he ended with soul welfare. 'Evangelical Dissenters have their unalterable convictions on the subject of religion ... They labour for the conversion of their children'. Mill Hill, where gathered 'the hopes of numerous households', was to train 'the gentleman, the scholar, and the Christian' as evangelical dissenters understood the concept. 'Whose heart does not involuntarily appeal to the Father of lights for his blessed working in the intellects, affections, and consciences of these young heirs of immortality?' 19

There is already here an Edwardian foretaste ('fathers of our faith and liberty') but the tone is surely Arnoldian, and Wells was speaking three years to the month after Thomas Arnold's death. It is also rhetoric for the age of Peel, a high flown but practical intensity, politically disturbed, socially excited, though not yet intellectually disoriented. There are tensions to be perceived in it.

It was decades before Mill Hill achieved the stability which Wells sought; indeed the school had to be reconstituted in 1869. Other Free Church schools suffered equally for the dissent which created them defined their constitution: since the great public and grammar schools were at once over protected and shackled by their endowments, dissenting schools should be proprietary schools, unendowed, relying on the success bred by success, reflecting the free trade spirit. Consequently they suffered. Even if Bishop's Stortford could get by with Felsted or Framlingham there could be no easy competition between Tettenhall and Rugby or Taunton and Clifton. They were affected in another way. They catered for families increasingly aware that they were in the social vanguard of the world's greatest and most civilised industrial nation. The inbuilt dissidence which created these schools kept them slim, but what kept them going was less social pioneering

18 Ibid pp 12-13.

19 Ibid pp 14-15. 


\section{Et Virtutem Et Musas}

than social conformity. The social vanguard of the new England which men like Algernon Wells hailed was far more likely to be a social guard's van, going where the age of steam took it. Thus the opinion formers of England's alternative society were harnessed to England's main society and since, though it was often touch and go, the dissenting schools survived, all of them eventually looking far beyond their immediate constituency, they formed over the generations so keenly anticipated by Wells a powerful agent in assimilation, perhaps in reconciliation; or perhaps they were simply the Trojan Horse in the chapel Troy, for if Dennis Smith is right in his contention that England's 'aristocratic-cum-clerical wing of the old order had particular success in shaping the new industrial society through the medium of formal education' to its own satisfaction ${ }^{20}$, the Free Church schools were willing partners in the process, with the Great War as its chief test.

The Great War was a test because through conscription, the nation's right to demand that its young men die for it, it brought the national emergency directly home to every adolescent boy. Inevitably it tested the accumulated assumptions of several generations of liberal education, carefully distanced from technical expertise but carefully geared to the tasks of competitive leadership. And after the War any distinctive Free Church peculiarities dissolved into an educational atmosphere. Increasingly most staff and certainly most boys in Free Church schools were off-comers.

In 1914 Mill Hill was at last where Algernon Wells would have wished, a dissenting Rugby, even a nonconformist Eton, if ever there had to be one, its boys working and frolicking in cousinly perpetuity. Since 1891 its headmaster had been J. D. McClure, big, cheerful and strenuous. 'I never met any Millhillian, even the rottenest, who had not an immense respect and love for him. ${ }^{21}$ McClure was Lancastrian Scotch, a Congregationalist, a barrister and musicologist, and doctor of both, from London and Cambridge. When he came to the school there were sixty one boys. At his death, thirty years on, there were three hundred and sixty one. ${ }^{22}$ McClure was more than his school's greatest

20 Conflict and Compromise, $\mathrm{p}$ xii.

21 (Kathleen Ousey) McClure of Mill Hill, A Memoir by his Daughter, (London 1927) pp 9, 276.

22 Ibid p 10. 
headmaster; he belongs to that smallish band of nationally known public school headmasters (literally so, he was elected to the Head Masters' Conference in 1895 and to its committee in 1910) whose school became their creation, plant and curriculum alike transformed. At Mill Hill the transformation began with Basil Champneys's Chapel of 1898. Champneys was a wonderfully apt architect. If his Newnham College, Cambridge, were all Kate Greenaway and his Mansfield College, Oxford, all John Wyclif, Mill Hill's new chapel was seventeenth-century as if Laud or 1662 had never been: ${ }^{23}$ stalls and organ case; barrel vault, strapwork plastered; a columned arcade to the apse and the right touch of baroquerie throughout. By 1914 McClure was an educational statesman, recently knighted, a leader in his denomination and in the world of music. And his school?

Schools are usually seen through official histories, which are success stories, or magisterial biography, which has a prejudice for its subject, or old boy memory, which cannot be neutral.

There is a fourth source: the school magazine. Naturally this cannot be wholly independent since, unless it is samizdat, it has been sanctioned by authority; but it has an immediacy denied to the other sources, and The Mill Hill Magazine claimed with some truth to be 'Conducted by the Mill Hill Boys'. ${ }^{24}$

The magazine had been running since June $1873^{25}$. Forty years on it reflected a sizeable school: two hundred and sixty one in November 1913, twenty seven of them day boys ${ }^{26}$. Its interests were predictable. 'Dear Sirs,-Don't you think it would be advisable to allow more people to change in the bath . . .?'27 And they were predictably chronicled: rugby football against The Leys and Eltham, Christ's Hospital and U.C.S., Haileybury and Merchant Taylors'; cricket against Whitgift and Highgate, Berkhamsted and Aldenham; and its own specialism, singlehanded hockey. Predictably too it is in sporting vignettes that the boys flash naturally to life. Thus Maurice Basden of the first XV,

23 As McClure put it at the school's centenary: 'I do not complain of the exclusion. Those to whom it was due knew what they wanted, and took the direct course to the realisation of their desires, and I know from my own experience how prone I am to be ruthless when I have my own way'. Ibid p 138.

24 Thus the title page of each issue.

${ }^{25}$ MHM, June $1923 \mathrm{p} 2$.

26 Ibid November 1913 pp 91, 93.

27 Ibid $\mathrm{p} 117$. 


\section{Et Virtutem Et Musas}

'A very tall forward who is most useful in the line-outs where he makes the most of his reach. Rather clumsy and has a poor wind. 12 st. ${ }^{28}$ Basden was killed in France three years later.

On most fronts the image projected is one of the professional and commercial and still Liberal middle classes in embryo, a junior bourgeoisie, boys of conscience, arguably of responsibility, carefully fostered. Their headmaster told the Old Boys that he was 'more than ever impressed with the importance of the Public Schools of England, if only they would rise to their opportunity and produce men who, in no spirit of superiority, but of sympathy and love, would endeavour to overcome the prejudices and malice of uncharitableness existing between class and class;' and he deplored 'the self-conceit and snobbishness with which the healthy spirit of esprit de corps too often degenerated amongst those who enjoyed great advantages'. ${ }^{29}$ The Hon. Lionel Johnston came in to tell Old Boys-to-be of the Cavendish Club, designed to arouse 'especially in 'Varsity and Public School men, a deeper sense of their obligations as regards social service' and he mentioned 'that on that evening ... the Prime Minister and the Archbishop of Canterbury were dealing with the same question at a great meeting in the Queen's Hall'.30 Millhillians were very much 'Varsity men, perhaps a dozen of them at Oxford and thirty at Cambridge in July 1914, their magazine letters full of the summer (Smith's 'white blazer and imperturbable calm brought him spotless through the wild "squashes" of punts, which follow the six o'clock race each evening ...') and the welcome promised to their successors - four on the line already for Oxford-in their

City of friends and echoes, ribbons and music and colour,

Lilac and blossoming chestnut, willows and whispering limes. ${ }^{31}$

Beyond this communal 'varsity face lay the Old Millhillians, for whom the magazine was no doubt chiefly composed, two hundred and sixty of them annually dining in October 1913, their marriages, births, and honours, sometimes their deaths, duly noted, a network of nonconformist success, generations thick, not yet wholly engulfed by suburbia or the home counties. In 1907, the

29 Ibid March 1914 p 149.

${ }^{29}$ Ibid November 1913 pp 98-9; December 1913 p 132

${ }^{30}$ Ibid.

31 Ibid July 1914 pp 52, 45, 47. 
school's centenary, there had been seven Old Millhillian M.P.s, all Liberals. This was a heritage whose motive power illumines the correspondent who felt that the new school houses, as yet A, B or $\mathrm{C}$, might 'imagine themselves to be the supporters of that stal wart Parliamentarian who resisted the encroachments of Charles I' or might be Brownists or Independents: 'for our part we are inclined to favour the chances of the Brownists. ${ }^{32}$ Perhaps this ancestral piety lies behind the ponderous fascination with socialism in essays, 'A man of original tastes, who shows a disinclination to submit to the conventions arbitrarily imposed by society, is usually labelled a Socialist, and hence anathema'; ${ }^{\prime 3}$ in correspondence, 'The Conservative and Liberal sections of the School each have their representative papers in the Scriptorium, why should not the Socialists also have theirs? I feel sure that there is a sufficient number of boys with advanced tendencies to make it worth while to introduce the Daily Citizen into the Scriptorium'; ${ }^{34}$ or verse:

Are the men of the age yet awake to the fact

That they're born in the world to their share,

Why should they that are men in this world full of health

Toil for those puppets which all of them hate,

Those accursed and fattening nurslings of wealth?35

This poem was severely taken to task by a boy ("I myself am a socialist in the purer interpretation of the word') who urged cooperation and dependency rather than revolution or equality, certain that 'sooner or later, the power will come into the hands of the labourers', fearful lest mere agitation would explode into civil war and so bypass the true misery of poverty, 'the impossibility of saving any money and the consequent ease of the descent into absolute beggary, the awful monotony of the work, and the horrible despair of unemployment, the depressing gloom and filth of the surroundings, the soul-destroying coarseness and vulgarity which pervades the whole atmosphere. These are the true horrors of poverty'.36

\footnotetext{
32 Ibid December 1913 p 136.

33 'On Labels' ibid November 1913'p 106.

34 Ibid March 1914 p 172. The editor replied 'The newspaper of the Socialists is the Daily Herald, which used to appear in the Scriptorium but was stopped by the authorities. The Daily Citizen represents the Labour Party'.

35 'Awaken' ibid April 1914 p 176.

36 'Awaken' ibid June 1914 pp 13, 15-16.
} 


\section{Et Virtutem Et Musas}

Here was progressive Liberalism, perhaps social democracy, happily comprehending votes for women, finding schoolboy parallels for the reasonableness of militancy and the hunger strike and debating (winning by twenty two votes to thirteen) that 'the State ought to take care of those who are incapable of taking care of themselves'. ${ }^{37}$

Here too was an enlarging of views, as in the review of an Old Millhillian architect's monograph on Baroque Architecture. Baroque was Romish, materialistic and artificial, but it also 'taught us many things about the broader aspects of architecture in an age when life was easy and spacious-how to plan and design on a monumental scale, how to make our surroundings less austere, how to glorify the gifts of Nature in garden and fountain, how to appreciate the grace of the human form, and lastly, how to beautify our cities'. ${ }^{38}$ Shades alike of Central Hall, Westminster, and Hampstead Garden Suburb; and of Mill Hill School Chapel too.

War is prefigured only in retrospect. The school had had an O.T.C. since 1911. It reached 'record numbers' in 1913 but its summer camp in 1914 would have to be cancelled because of german measles. 'As the prospects of a large number attending camp were very bright, this is particularly unfortunate'. ${ }^{39}$ Bisley's 'splendid sporting fortnight' was a fixed point of the school year..$^{40}$ In March 1914 library accessions recorded With the Victorious Bulgarians and a volume on aviation. ${ }^{41}$ The same number contained an account, natural in a school proud of its German, of eleven weeks in Germany, factual rather than friendly. ${ }^{42}$ There was one instance only of 'invasion' literature: a grim little story of guttural voiced invaders and fifth columnists (waiters and second-hand clothes dealers) and sudden death..$^{43}$ That was in June 1914, an issue whose frontispiece showed 'Clark finishing the Half Mile in

37 thus 'Votes for Women' ibid March 1914 pp 150-4. This, like the essay 'A waken' was by G. B. B[arber], 'A strong forward who is hard to stop. Should be good next year with a better knowledge of the game.' Ibid p 150. Also pp 164-5.

38 Norman Brett James' (master and commandant of OTC) review of M. S. Briggs, Baroque Architecture, 'Baroque Architecture' ibid December 1913 pp 132-5.

${ }^{39}$ Ibid November 1913 p 92; July 1914 p 73.

40 Ibid June $1914 \mathrm{p} 38$.

41 Ibid March 1914 p 170.

42 'A Short Visit to Frankfurt-On-Main', ibid pp 160-3: 'German police require to be armed with a sword at their waist-a London policeman by raising one hand stops an endless stream of traffic'. (p 161).

${ }^{43}$ N. M. G[oodman], 'War: An Incident' ibid June 1922 pp 33-4. 
Record Time', head flung back, arms out wide, while straw boatered prefects stood in nonchalant appreciation by the finishing post. ${ }^{44}$

In one respect Mill Hill had a good war. Its numbers rose from two hundred and seventy nine in 1914 to three hundred and eighteen in 1918 and perhaps it suffered less than some from the inevitable importation of superannuated temporary staff. ${ }^{45}$ Indeed there were positive advantages in the arrival of so old a Radical hand as C. A. V. Conybeare in 1916 or Prebendary Ross of Wells in 1917.46 Nonetheless the cumulative impact of war, unrelenting, its reality extending into 1919 and beyond, may be charted in five distinct ways. There is the sense in which the school became unassailably part of the national public school community, nature's officers all. There are the editorials and letters to the editor. There are the essays and poems, notes on occasional lectures and debates, lists of library accessions. There is the most obvious impact of all, that on the Old Boys. And there is religion, which ought most naturally to be obvious but is in fact the most elusive to identify, perhaps because it was assumed to be as much part of the warp and woof of Mill Hill life as of all public school life.

The sense of public school fraternity is conveyed by the magazine's contemporaries. In 1917, for example, these included the Cheltonian, Epsomian, Marlburian, Malvernian, Sedberghian and Felstedian, but also the Boys' Brigade Gazette and College Echoes from Anglo-Chinese College, Tientsin. ${ }^{47}$ Sometimes their contents were reproduced. Thus, again from 1917, the Shirburnian's ode, 'Pro Tot Tantisque Beneficiis', ending:

For the lessons taught to the ageing by eager striving of youth,

By the firm unswerving devotion of all man's being to Truth, For making the most of the throw of the dice, be it even or odd,

And, beyond and above the rest, for the long-sought vision of God,

44 The record time was two minutes, twelve and four fifths seconds, ibid $\mathrm{p} 17$.

45 Ibid November 1914 p 89; November 1918 p 40.

46 C. A. V. Conybeare (1853-1919) was a barrister who had been M.P. for Camborne from 1885 to 1895 , and briefly imprisoned under the Coercion Act in 1889.

47 MHM November 1917 p 89. 


\section{Et Virtutem Et Musas}

Sherborne, I thank thee!

Or a last stanza from The Leys Fortnightly:

$O$ England, guard thine ancient faith and freedom!

Oh, hear us who have died!

What if thy heart, when now the world most needs it,

Should fail through lust or pride?

Our bodies we have broken: shall our spirits

Also be crucified? 48

At Mill Hill there was no cricifixion of spirit and there was a level headed sense of proper freedom. ' $[T]$ his is primarily a School Magazine and intended for School news', the first wartime editorial announced before turning to the half dozen 'who have sacrificed their school careers in order to join the colours,' and to the Old Boys, over three hundred of them already serving their country, filling the school "with pride, aye, and with something not very far removed from envy'; and to the O.T.C. which 'Practically the whole School has joined'; and to football:

Some people even go so far as to say that all games should be stopped during the war . . . we would like to suggest that Football is an essential part of school training . . If any one intends to try for a commission. . . it is Football that can train his mind and body and fit him for the service of his country. The boy who can go down to a forward rush, or go 'all out' for a try, will yield good enough material even for an officer. Waterloo was won on the playing-fields of Eton. Then, before Heaven, let this struggle be won on the Rugger fields of Mill Hill and her compeers. ${ }^{49}$

The message was consistent. In December 1914 "every day finds us even more impatient to be up and doing something for our country'. ${ }^{50}$ By March 1915, although 'by the time you read this, Germany may have given in and the war have been finished or London may have been destroyed by Zeppelins' it was more likely that 'the war may still be going on next year, and possibly-who knows? - the year after that. We begin to count the days to that time when we, too, shall be free, and to wonder whether there may not after all, be a chance even for us....-So each, at his

4 Ibid pp 87, 89.

49 Ibid November 1914 pp 77-9.

50 Ibid December 1914 pp 115-6. 
appointed time, breaks from the ordered life of School, and goes out to do his bit whatever that may be . . '51

That year's Christmas number was to go to each serving Old Millhillian. 'In all parts of the world, wherever British troops are stationed, Old Boys are inevitably thinking of home just now, and then their thoughts turn back to their old School . . . the rags they took part in, the masters they were under . . . whatever may have been their position in school . . . they are part of the School'.52

By 1916 the war was routine fact ("Economy envelops us successfully') though still to be welcomed bravely. 'Some of us are treading the speedy way of school-life for the last time, but the usual melancholy sentimental feeling of farewell does not come to us as it came to those who left in a former day-we are actually pleased to ... step into the sterner discipline which we meet forthwith'. ${ }^{53}$

That discipline was now no longer voluntarily embraced, hence the shadow behind November 1916's knightly editorial: 'Militarism seems to envelop us on every side'. ${ }^{54}$ The sense of compulsion, however willingly accepted, deepened. 'The Government has required each of us this term to spend a specified time ... on agricultural work; this is necessarily taken out of school hours. In addition to this compulsory work an appeal has been made for voluntary work on half-holidays . .., the response has been in every way worthy of the School.'s5 So to 1918: 'the belated summons has reached us; we are bidden to exchange the pen for the sword'.56 'Us' was W. E. Bater, a delayed classical exhibitioner at Christ Church, Oxford. His school career precisely spanned the war. There were three more war editorials. That for June 1918, reflected that all who have edited this Magazine during the last four years, and, for aught we know, for years before that, have served their country in active warfare. Now, . . . we wonder whether we may ever have the fortune to serve with them.' 57 That for July began baldly, 'It is an unfortunate fact that there is a war on . . . and went on: 'Shooting and farming

\footnotetext{
31 Ibid March 1915 pp 139-140.

52 Ibid December 1915 pp 85-6

53 Ibid April 1916 pp 147-8.

54 Ibid November 1916 p 61.

55 Ibid June 1917 pp 2-3.

56 Ibid April 1918 p 150.

57 Ibid June 1918 p 1.
} 


\section{Et Virtutem Et Musas}

have claimed their weekly and daily devotees'.58 That for November was the first to make no reference to war. ${ }^{59}$

An editorial needs the balance of correspondence. Much of the magazine's was predictable and pseudonymous. The five correspondents of July 1915 ranged from 'Decorum', on leaving chapel after service, to 'Balls', who asked why so many cricket balls were lost. ${ }^{60}$ In spring 1917. a Bournemouth Old Boy wrote in. He was what "an American would describe as "mad" ' at "No Glutton's' defence of the school tuck shop:

Nobody enjoys seeing a schoolboy have a good 'tuck in' more than I do, but in the present circumstances it's not 'good form'. Boys, as well as 'grown-ups', can help in this war, and I would like to see Mill Hill boys take the lead by closing the Tuck Shop till Lord Devonport says our food and our sugar supply is all O.K.

It took 'Magister' to calm the gallant captain with chapter and verse as to the school's war consciousness. ${ }^{61}$ It was a different sort of letter, most poignant in the war's first year, which underlines its impact. In April 1915 'Virtutem et Musas' suggested that 'a photo of the Head Master be put in, as I feel sure that the Old Boys, especially those at the front, would be pleased to have it; and secondly ... photos of our Old Boys who have been killed in action'. ${ }^{62}$ Previous issues had printed extracts of letters from the Front, all cheery ("We went to a ripping concert last night . . . It was an awful rag . . .'), a few uncomfortably factual beneath the cheer and the clean-limbed slang, some recreating the school community ("Another section in our platoon consists almost entirely of Old Leysians, and nearly every other School is represented in the regiment'). ${ }^{63}$ One of them, covering a Sunday and a Monday in France, may stand for the rest:

... It was gorgeously fine, bright blue sky. At 10 am in the morning we had service . . 300 to 400 there I should think. Well, anyhow, it was a splendid service, but it was one of the

58 Ibid July 1918 p 19.

59 Ibid November 1918 p 39.

so The others were 'Lance-Corporal', on the role of NCOs in the OTC; 'One who tends to always split his infinitives', and 'Seven Vols of Tennyson's Works' who 'would jolly well like to know why we have completely vanished from the Library'. Ibid July 1915 pp 53-5.

61 Ibid April 1917 pp 175-7.

62 Ibid April 1915 pp 199-200.

63 Ibid March 1915, p 153, 152. 


\section{CLYDE BINFIELD}

most extraordinary I've ever been to, for the day was perfect for aeroplanes, and right in the middle of the service would come the bang, bang, bang of the aeroplane guns, and the chatter of the maxims. I've seldom heard better singing, and then in the last hymn the climax was reached in a splendidly sung 'Stand up, stand up for Jesus', just as our big guns roared out; it made one rather smile-

'This day the noise of battle',

Well, we hope the line goes on ...

Next, some comrades' graves, beautifully turfed, nicely fenced, prelude to a Monday morning march

Splendid for aeroplanes, and a beast of a German spotted us ... It was a topping march, I can honestly say I thoroughly enjoyed it, though it lasted five hours and more... Moreoever, I spent quite a cheery time meeting friendsDay, of Mill Hill . . . young Russell-Smith, sometime of Johns, and Mr. Gemmell, late my Form Master at Mill Hill; meeting him was rather humorous, as he now is my junior, being a second Lieutenant . . . I am in splendid condition, as hard as a bell. 64

German beastliness was seldom obtrusive even in the magazine's slender literary content, its essays, stories, poems, occasional reviews. Some of these were thoughtful although few sustained the level of 'Civilisation' with its conviction that war and civilisation are incompatible, its suspicion that 'even when war and extreme poverty are eliminated, civilizations may not be tending in the right direction', its determination that this should be the last war and 'that the evils which war does help to cure, must be cured speedily by other means'?65

If 'Civilisation' was in a spirit of Liberal internationalism, 'Great Britain and the War' was in the spirit of Liberal imperialism and Kipling's Recessional. ${ }^{66}$ It was a résumé of J. A. Cramb's England and Germany (1913) with its thesis that history's underlying motive is the desire for empire, 'a national creed almost religious in its intensity . . . the restless craving for a better state. . 'Thus Germany, 'the youngest, most vitally alive nation in Europe, imprisoned on every side . . .' is, beneath and despite

of Ibid April 1915 p 179.

65 'Civilization' Ibid November 1914 pp 79-83.

to first published in The Times in 1897. 


\section{Et Virtutem Et Musas}

the tawdry disguise of Prussian bombast and Nietzschean philosophy, 'secure, indomitable, serene, richer in mind and spirit, richer in energy and vitality than any other foe that England has had to face'. These were no 'sausage-fed, beerswilling myrmidons' and this was to be a long conflict, and a crucial one, for it was Goth against Rome, and the question must be, was England, 'at that stage of a nation's career where expansion has ceased and stagnation begins to appear,' to follow Rome? 'Can we show the world that Britain, at any rate, is not like other Empires, that her spirit is immortal, indomitable, her glory, based on the true foundation of Christianity, is permanent, enduring to the end?' 67

G.S. could not agree. To 'Great Britain and the War' he replied with 'Mankind and the War', a return from imperialism to internationalism, distrustful of the secret diplomacy of great powers. For G.S. the pre-war 'restless craving for a better state' was not fuelled by the ideals of empire, anachronistic and hardly Christian, but by 'a body of thought which is growing out of science and the changed social condition, - a philosophy which is of man, not of nation or class; international, great as the world'. And the path of duty was clear.

We must smash German militarism; but we must also make sure that the people, of whom we are a part, have some control over those forces which, working in the dark, can without a word of warning plunge the whole labouring world into a hellish struggle such as this, which has neither rhyme nor reason. ${ }^{68}$

Here perhaps was the authentic Mill Hill. It showed itself in March 1916 on 'Heroism', clumsily recognising the heroic element in Quakerism. ${ }^{69}$ It was there again in December 1917 on 'Peace and War' with the development of an Asquithian text: 'We must banish once and for all the time-honoured fallacy that if you wish for peace you must prepare for war'.

Strange to say, there are even some to whom the chief lesson of the present war is that we must never again allow ourselves to be caught unprepared. . . Has any nation ever gained for

67 'Great Britain and the War' MHM March 1915 pp 141-5.

68 'Mankind and the War' ibid April 1915 pp 182-4.

69 'A new order should be instituted by the King for men who stand up for their views against all comers', and it quoted Emerson 'Heroism' Ibid March 1916 Pp 120-2. 
itself a reasonable period of true peace by means of preparation for war?

This essayist was an optimist: human nature must change, we must effect the change, for that is our duty, and at last we have the agent for this change in the 'magnificent cosmopolitanism' of a great idealist statesman, Woodrow Wilson. ${ }^{70}$ Then the tone changed. Heavy humour came to the fore; or travel ('Wild Elephants in Burma'); or a past master's 'Eight Months on the Land', a pastoral of 'pure air and sweet odours, sunsets and rising mists-God's earth, man's purest joy!'; or the Boy's Own conquest of the air, that ultimate fascination ('A Daylight Patrol'; 'The Raiders'); or a word from the O.T.C.'s old sergeant on musketry: 'rub in all you know to your own men ... Get them keen and interested, and make it your duty to press each man until he reaches the highest standard in this very important branch of his training. ${ }^{71}$

This reinforced the sentimental element, never absent, that was more naturally expressed in stories or verse . . 'Le Drapeau' was a tale of the spirit of Alsace; 'The Iron Cross' told how pompous little Carl von Essenheim really won promotion. ${ }^{72}$ These were stories. The poems were more numerous: "To the Special Constables who Guard the Armoury'; the grumbling Cockney of 'Unto Them Be the Glory' who 'charged the enemy's trenches to the lilt of a music-hall song' ${ }^{73}$ the grumbling lady tea-gossiping over 'Those Belgians', until told:

Now is not the time for scandal,

Think what Belgium's done for you.

Try to picture their position;

Try to take a broader view. ${ }^{74}$

Or, simply, 'Tomorrow':

They'll call us next, boys,

To battle the stern tomorrow,

It won't be, perhaps on the battlefield, Playing our country's game;

70 'Peace and War' ibid December 1917 pp 104-8.

7 Ibid November 1918 pp 49, 53-5; March 1918 pp 131-4; July 1918 pp 20-2, 28-9.

22 Ibid April 1915 pp 187-9; July 1915 pp 35-7.

33 Ibid November 1914 pp 83, 108.

74 Ibid March 1915 pp 158-9. 


\section{Et Virtutem Et Musas}

May be in the office or workshop,

But it's fighting just the same. ${ }^{75}$

That call persisted throughout 1915, a moral conscription for boys whose school was now all about the officer class and empire's duty, though their families had never fought.

Have you forgotten the deeds of your sires, Britain made great and her Empire free?

Rally again, lads, the nation requires, Service from you, lads, and service from me. ${ }^{76}$

Changes were frequently rung. In 1917 there were sombre sonnets

And mothers weeping with a rueful joy

At Death's serene, unsearchable abyss. 77

'Instability' was naturally about British steadfastness, 'the seed

Of an immense, an unconquerable breed

Which, being free, is yet at God's command.78

In 1916 it had been personalities, Joffre, "heaven-sent leader of our ancient Gaul' or Kitchener:

O rocks of the Orkneys, relentless and ruthless.

What did you see of our Kitchener's end?79

In 1915 it was epic outrage, the three parts and forty stanzas of 'Louvain' (to rhyme with 'chain') contrasting with the swift schoolboy vogue for the Hymn of Hate. ${ }^{80}$ In March 1916 the magazine reprinted Christ's Hospital's 'The Persevering Hun'. This concerned Von Humperstein's airship crew who

Sang the Hymn of Hate

From half-past six to half-past eight,

As Teuton warriors of late

Habitually do.

A month later Mill Hill produced its own Von Gumboilbosch, 'a really true-bred Hun',

(Did I describe Von G. to you?

A florid, horrid man)

He sang with glee the Hymn of Hate,

As only a German can. ${ }^{81}$

${ }^{75}$ Ibid $\mathrm{p} 163$.

76 Ibid July 1915 p 35.

7 Ibid July 1917 p 52.

78 Ibid December 1917 p 96.

79 Ibid June 1916 p 6; July 1916 pp 27-8.

Bo Ibid June 1915 pp 6-10.

8t Ibid March 1916 PP 145-6; April 1916 pp 150-1 Christopher Isherwood, in April 1916, at 
School magazines are not places for subtlety. Everythinghumour, sentiment, morality-is heavy. Toleration is tolerable only as a plea for fair play. There can be little doubt as to the general mood in the school. In March 1916 the magazine congratulated three award winners, two to Cambridge, one to Oxford. One of these was B. K. Martin, the impossible parson's son, who had entered Mill Hill as a day boy in 1914. 'Success sometimes finds the right people'.82 As Kingsley Martin of The New Statesman, B. K. Martin had mixed recollections of his last school. He respected, indeed liked, McClure, "wonderfully tolerant of my eccentric attitude to the war' ${ }^{83} \mathrm{He}$ respected the classics master, John Hampden Haydon (the forenames tell all), who coached him for his scholarship, more in retrospect than in actuality. He disliked school sport; and as a consequence of facing a tribunal as a conscientious objector while at school (the commanding officer of the OTC, Norman Brett-James, the school's historian, spoke up for his sincerity) he found himself turned out of his study, boys hitting him on one cheek to see if he turned the other one. He wrote a defence of his views for the magazine 'which was refused because it was thought to reflect badly on the school's reputation' ${ }^{84}$

Yet it is hard not to feel that Martin's unpopularity (and he was, even so, a prefect) was a matter more of personality than of views, of manner rather than content. Indeed he recalled that he won a measure of respect for his stand, his rejected essay passed round and read by some of the older boys. As has been seen, the magazine had printed varying, even moderately dissenting views on the war, and in June 1916 it printed a jeu d'esprit by Martin, 'The Caprices of Clio', redeemed by his aside on 'the Christian Sergeant O'Leary who killed nine Germans single handed (This, we are told, does not constitute a record. Some years before, one Samson killed forty Philistines with the jaw bone of an ass)' 85

Saint Edmund's Hindhead wrote a 'Lay of Modern Germany:

Then out spoke fat Von Winklepop

Who composed the 'Hymn of Hate'

B. Finney, Christopher Isherwood: A Critical Biography (London 1979) p 32.

${ }^{82}$ MHM March $1916 \mathrm{p}$ 119. Impossible Parson is the title of his father's autobiography:

D. B. Martin, An Impossible Parson (London 1935).

${ }^{83}$ K. Martin, Father Figures: a first volume of autobiography 1897-1931 (London 1966) p 58.

${ }_{84}$ Ibid $\mathrm{p} 66$.

${ }^{85}$ BKM 'The Caprices of Clio' MHM June 1916 pp 8-10 especially p 9. 


\section{Et Virtutem Et Musas}

That year the magazine's 'Valete' listed twenty boys. Eighteen of those were in the cadet corps. Of the remaining two, one joined up and the other, Kingsley Martin, went into the Friends' Ambulance Unit. ${ }^{86}$

In the previous year the magazine had listed the seven hundred Millhillians already in the forces. ${ }^{87}$ It calculated that nearly eighty per cent of Old Boys between the ages of nineteen and forty served in some capacity; twenty-nine had died on service and forty-seven had been wounded; there were two DSOs, an MC, a Croix de Guerre, a Russian order, and six mentions in despatches. Sixty-one served in a medical capacity, chiefly in the RAMC, but there were five with the Red Cross, and two in the Friends' Ambulance Unit. And there was one 'Chaplain to Forces at Cambridge', ${ }^{88}$ an interesting, indeed mystifying, inclusion because he was $\mathrm{H}$. C. Carter, minister at Emmanuel Congregational Church, Cambridge, and a notable pacifist. Five hundred of the seven hundred Old Millhillians held commissions, but only nine were of colonel's rank. Such figures are tributes, striking yet unsurprising, to the pressures of volunteering, to the extent to which a dissenters' grammar school was assumed to produce officer material, ${ }^{89}$ and to the novelty of what was now an almost universal experience. Mill Hill, its OTC notwithstanding, had no service tradition, for the armed services were not a natural career for Mill Hill families. Overnight, or at least over-year, the army, with the navy some way behind and with the airforce still the most captivating of dreams, had become a fact of life. Conscription merely dotted the i's.

The speed of it needs stressing. The first wartime magazine listed three hundred and forty nine serving Old Millhillians, their years ranging from. 1873 to 1912 , among them, although it was a while before the news reached the school, a French foreign legionary, and one of the school's first peers, Lt. Col. Lord Rochdale, 6th Batt. Lancs. Fusiliers, in Egypt. Two Old Boys had died in action, one in East Africa and one at Antwerp; the OTC's sergeant major had been killed in a local motor accident; and each

Bo Ibid July 1916 pp 54-6.

${ }^{87}$ Ibid December 1915 pp i-xviii.

as Thus ibid $\mathrm{p}$ iv.

89 None of the eleven school servants listed in addition to the seven hundred Old Boys held a commission; an unsurprising fact which should nonetheless be noted. 
of the three November school leavers had been in the OTC, and two of them were now attached to regiments. ${ }^{90}$

The OTC came inevitably to the fore. In November 1914 it had two hundred and twenty three members (with twenty probationers), it paraded twice a week, was lectured to twice a week, had a Saturday route march and dug lots of trenches. ${ }^{91}$ By the following summer 'all but seven of the School are being trained' and next November its band 'gave a creditable performance in the village' escorting fifty recruits enlisted under Lord Derby's scheme. 92

The bands and the field days were the gloss on a reality in which sports days had become attenuated, prizeless affairs, monies raised from them sent from the 'Public Schools of England' to a hospital 'somewhere in France', and in which physical activity had become a statutory matter of ten hours' military service a week for all eighteen year olds, seventeen year olds as well by 1917, with two of the ten hours taken from prep. ${ }^{93} \mathrm{~A}$ grimmer reality lay in each issue's lengthening 'legio Millhilliensis', seven of them killed near Ypres in late spring 1915 and three in the Dardanelles by June; twenty-seven killed on the Somme in 1916, among them the foreign legionary. ${ }^{94}$ No wonder a contribution dwelt on the envelope 'On His Majesty's Service' with its yellow slip of paper: " "You are required to present yourself for service with the colours ..." The shock has come. He is a man'.95 And the Oxford and Cambridge Letters of pre-war years were replaced by a Sandhurst Letter, for now there were five Old Millhillians at Sandhurst, with four to come, one of them from a Congregational manse. "My mind was sore troubled . . . at Waterloo; would a third-class ticket suffice or should one consider oneself already an officer and therefore in bounden duty be forced to take a first-class ticket?' 96

9o MHM November 1914 pp 92-102, 88; for foreign legionary Rieu see ibid March 1915 p 147.

91 Between 1911 and 1914 the OTC had already produced one hundred and forty Old Millhillians of whom ninety were in the forces, one hundred and twenty by June 1915, with eighty holding commissions. Ibid November 1914 pp 101-2; June 1915 p 20.

92 lbid December 1915 p 106.

93 Ibid March 1915 p 161; November 1916 p 79.

94 Ibid June 1915 p 3; July 1915 p 31; November 1916 pp 62-64. And an elderly Old Millhillian was drowned in the sinking of the Lusitania, ibid July 1915 p 43.

95 Ibid March 1917 p 150.

96 So he purchased a first class ticket, only to discover that third class smokers had been reserved for 'gentlemen cadets proceeding to Camberley'. Ibid July 1916 pp 33-35 especially $\mathrm{p} 34$. 


\section{Et Virtutem Et Musas}

It was some time before the listed deaths were illuminated by any suggestive detail. W. H. Andrews, whose starting of the rifle range had 'made the way easy for the O.T.C.', was the French master, 'chary of showing any emotion other than laughter', who compiled the lists of the legio Millhilliensis. ${ }^{97}$ E. L. Milner-Barry, of Naval Intelligence, who had come with McClure and gone on to a chair in Bangor, was the German master. 'Years before the crash came, the gathering cloud . . . was visible to him, and the thought of its inevitableness filled him with foreboding . . . for there was much in Germany that Milner-Barry loved as well as much that he hated, and he knew how terribly strong she was. ${ }^{98}$ As to those killed, the myth (perhaps the essence?) is captured by the reproduction of Frank Salisbury's 'very speaking portrait' in airman's uniform, exhibited at the current Royal Academy, of his nephew F. T. E. Stafford, shot over the German lines, who died on St. George's day, $1917 ;{ }^{99}$ or by the recollection of Owen Lapthorn, killed in France a month later, who had 'a wonderfully clear idea of the meaning of the war, and ... had felt a moral compulsion to fight'; 100 or in Alec Boardman's letter home, just before his death on Salisbury Plain:

There have been a good many accidents here because the weather has been so bad, but please don't let mother know, else she will only worry. Anyway, I am not frightened because my life is in greater hands than any stunt pilot's. ${ }^{101}$

From 1916 all school boy life ended in the war. Was there a reciprocal relationship? There was certainly a literary relationship. In November 1914 'Entente Cordiale' pleaded the cause of French books ("Let German "culture" plead its own cause-I will not') for the library whose six thousand volumes lacked any Molière, La Fontaine, Hugo, Daudet, de Musset; indeed 'Entente Cordiale' claimed that barely six works of French literature were to be found in it. ${ }^{102}$ Perhaps so, and the advice was acted upon. More obviously the war encouraged the regular presentation of Germany's Swelled Head, How Germany Makes War,

\footnotetext{
97 Ibid June 1917 pp 11-13.

98 Ibid $\mathrm{pp}$ 13-14.

99 Ibid $\mathrm{p} 7$ with a reproduction of the painting.

100 Ibid July $1917 \mathrm{p} 28$.

101 Ibid June 1918 p 4.

102 Ibid November 1914 pp 113-14.
} 


\section{CLYDE BINFIELD}

Britain's Case Against Germany, The Prussian Hath Said in His Heart, To Ruhleben and Back, Sixteen Months in Four German Prisons, as well as Rupert Brooke's Poems and War Letters of a Public School Boy. ${ }^{103}$ Another literary element is found in an Old Millhillian review, Basil Matthews' The Secret of the Raj, published by the United Council for Missionary Education and 'splendidly designed' to interest schoolboys. Matthews was made to harness the imperial dimension, necessarily also a missionary one in such a school as Mill Hill, to the war: 'One of the most remarkable features of the present war is the absolute ignorance of our enemies as to the real nature of the British Empire'. It was Matthews' thesis, so the reviewer felt, that there was 'a kind of Fate driving Englishmen to devote their lives to the task of government . . . The English rule stands out as the one possible central government, pure, altruistic, and reliable, and having in the eyes of the native something of a supernatural sanction.' Altogether, 'in view of the tremendous problems in India needing solution in the near future, this is emphatically a book to read'. 104

There was a mounting awareness of problems beyond the bounds of war lying nearer home. New Foundation Day (Public Day's replacement), 1915, was addressed by H. A. L. Fisher, then vice-chancellor of the university of Sheffield. He spoke breezily of 'the cleverest nation upon the face of the earth. '105 But educational reform was in the air. Indeed, that was the opening sentence of a paper on the matter in November 1916 by one of the masters, J. P. Howard. It proved to be a plea for the traditional values of a humane education by a man 'lamentably ignorant of even elementary science,' horrified at the prospect of a school comprising boys (all those Spicers and Willses) "whose industry in the class-room was regulated entirely by motives of pecuniary gain and worldly position,' designers of a world in which 'Chemistry is to be the chief end of life since chemistry is useful for farming!' Howard was comforted by what a London professor of engineering had said to him last Easter holidays: 'I would rather have boys coming to me quite ignorant of engineering and with a sound general education, than boys who have specialized too soon

103 Ibid April 1915 p 193-4; December 1916 p 123; June 1917 p 24; June 1918 p 16.

104 Ibid July 1915 pp 41-2.

105 Ibid November 1915 p 68. 


\section{Et Virtutem Et Musas}

at the subject and whose general culture has been neglected.'106 Therein lay right thinking in the matter of educational reform.

But it meant nonetheless that the public schoolboy's world was never again to be unquestioned. 'How many people ... have noticed ... the disappearance of the top-hat as the Sunday headgear of our Monitors?' or the stiff collar, or, who knew, the tail-coat? 'Considering that the most liberal estimate would limit the days on which it is worn to a score per term, and that on leaving school the wearers almost immediately don His Majesty's uniform, the tail-coat would seem to be a foolish extravagance. '107 That was in July 1917. In November the magazine went beyond appearances to quote approvingly from a new Repton periodical, with pieces on Democracy (urging 'an open road for talent, an aristocracy of intellect, will and determination ... from the Elementary School to the Universities') and Revolution ('something has been changed, an angel has passed through the air ... A new set of ideas, of standards, of ideals has been liberated') and Public Schools after the War. This piece urged government scholarships at public schools for elementary school boys, and it stressed that any public school reform must start from within the schools themselves. The establishment must defuse its own revolution. ${ }^{108}$ That was the message when W. E. Bater and two friends reviewed Alec Waugh's Shirburnian succés de scandale, The Loom of Youth, (pro tot tantisque beneficiis?) for despite its kernel of 'very real truth', most of its abuses 'can be reformed (without the necessity of rooting out the whole system) by the Public School boy himself, and by him alone'. ${ }^{109}$ At a more exalted level that was what Balliol's A. L. Smith told a cloudless Foundation Day in July 1917: come peace, there would be no new English civil war between capital and labour, for education would prove a chief preservative of social well-being. ${ }^{110}$

The underside of this was the Literary and Debating Society, asleep since October 1914 but revived in March 1916 by Captain Brett-James of the OTC as a light-hearted inconsequential thing which nonetheless stumbled through reform of the public school

106 J. P. H(oward) 'Reform in Education' lbid November 1916 pp 84-8.

107 AHM 'The Old Order Changeth' ibid July 1917 pp 34-5.

108 'A Public School Looks at the World' ibid November 1917 pp 75-6.

109 Ibid March 1918 pp 138-40.

110 Ibid July 1917 p 32. 
system and class proving the ruin of England in the near future and pacificists being a menace to the state who should be deprived of their civil rights. That debate was marked by talk of the Kaiser in Westminster Abbey and conchie guards helping German prisoners to escape; but its result was a foregone conclusion. The motion was defeated by six votes to thirty four. Deprivation of civil rights was unBritish, indeed as W. E. Bater reminded his audience (to their applause), it was unMillhillian. Why else had their school been founded?111

Perhaps this was McClure winning through. Martin Briggs, the Old Millhillian architect, apparently captivated his audience with 'Michael Angelo' in October 1914: 'a lecture on art delivered to a boys' school at a time like this . . .?'112 From December 1915 there was a campaign, perhaps mounted by McClure and therefore successful, for a musical society. ${ }^{113}$ In 1916, thanks to the tercentenary, "we ... have been inoculated with Shakespeare. We think Shakespeare, we talk Shakespeare, we act Shakespeare.' 114 In 1917, amid patriotic British and American songs, it was Benjamin Franklin's turn. A hundred and fifty years earlier he had stayed in Mill Hill. Now in a set surrounded by trees planted by Franklin's Quaker friend Collinson, a play by Captain BrettJames discussed electricity, daylight saving, and the perils of German influence. ${ }^{115}$

One dog has yet to bark: religion. Mill Hill's Christianity was still recognisably Free Church Christianity, probably more Congregationalist than anything else. Old Millhillian weddings tended to be chapel weddings rather than church; and school chapel was Chapel, not Church. But it was also a public school Christianity: 'Surely the aim of a religion is to keep men straight, and the religion which does that best is the most successful, whether it be ours or not. '116 Neville Goodman's poem 'Revelation', phrased this with more sophistication:

Fiercely rebelling, I cursed Him and straightway expected to die,

111 Ibid April 1916 pp 163-5; March 1917 p 154; November 1917 pp 83-4.

112 Ibid November $1914 \mathrm{p} 112$.

113 Ibid December 1915 p 116 (was McClure himself the correspondent, disguised as 'Out of the Mouths of Babes and Sucklings'?); April 1916 p 170.

114 Ibid July 1916 p 26 , with review, and photographs, pp 45-9.

115 Ibid July 1917 pp 44-5.

116 'Heroism' ibid March 1916 p 122. 


\section{Et Virtutem Et Musas}

When God in His mercy pitied and I heard a voice from on high-

'To true seekers of Light, God ever reveals,

God the true God is the God of Ideals.' 117

In the school its focus was of course the chapel, which chiefly appears in the magazine as a blackout problem and already too small and the source of schoolboy nightmares. ${ }^{118}$ Even so, in December 1915 'Custos' wanted to know 'why we hear so little of the war in Chapel?' The war litany has ceased, the national anthem is never sung, sermons make no reference, indeed 'Mr. Pearson's sermon of a few weeks ago on David and the well at Bethlehem, and the searching question, 'A re we worthy of the sacrifice?' were the first reminder that many of us have had for some while of the war and its meaning for us all.'119

Yet such reminders appeared with increasing frequency in the magazine. 'Well Dad, we are going up the line soon. You know what the student told his men: "If wounded, Blighty: if killed, the Resurrection". If the great possibility happens, think of me only as part of a great stepping-stone on which the world will rise to better things.' 120 Thus a letter home; thus too an encounter between the Merchant Taylors' padre, 'a short, square-shouldered humorist, who owned to damaged knee joints collected on the football field,' and who was about to read the burial service and so commit some of our lads, 'to the care of the great G.O.C. of us all', and the weary Millhillian liaison officer, who recalled a famous victory against Merchant Taylors' ('Footer turns boys into men at Mill Hill') and reflected that 'the Padre was a better padre because he led the school pack, and I hope that I am a better officer because I, too, once wore the chocolate and white.' ${ }^{121}$

This is a flavour best distilled in 'Sentences from a Charming Book' a magazine selection by an Old Millhillian Congregational minister. Ernest Hampden-Cook, from a Canadian Old Millhillian's (and manse son's) letters home:

I am setting out on a crusade. . I have a growing trust that

117 Ibid December 1914 pp 133-4.

118 'For the Choir Secretary to find that the Head Master's list of hymns does not agree with the organist's, and the boards both tell a different tale'. Ibid March $1916 \mathrm{p} 136$.

119 Ibid December 1915 p 113.

120 Ibid July 1918 p 23.

121 'Reminiscences' ibid November 1918 p 46. 
whatever God decides for me will be best and kindest ... We've been carried up to the Calvary of the world, where it is expedient that a few men should suffer that all the generations to come should be better . . . Life has become so stern and scarlet-and so brave! Today I am genuinely happy, for I feel that I am doing something which has no element of self in it. The men are splendid . . . and when the governess, Death, summons them to bed they obey her with unsurprised quietness . . . I am quite disillusioned about the splendour of war. The splendour is all in the souls of the men who creep through the squalor like vermin. Poor lonely people, so brave and so anonymous in their death! ... When you see how cheap men's bodies are, you cannot help but know that the body is the least part of personality . . . Dimly one thinks he sees what is right, and leaves father and mother and home as though it were for the Kingdom of Heaven's sake. Perhaps it is. One can't explain. ${ }^{122}$

Mill Hill's war could not end with the Armistice, although that was delight enough, with a verse competition, the national anthem in the Large, a service of thanksgiving in the chapel, processions with flags and tea-trays round the top-field and into the village, and, culminating joy, a guard of honour for the king and queen, with tea from Sir Albert Spicer, shared with The Leys, at the Free Church Thanksgiving in the Albert Hall. ${ }^{123}$

The prime practical issue was an appropriate memorial for the hundred and ninety-two killed on service out of the eleven hundred who had served. ${ }^{124}$ This had been in train since the

12

123

Aid December 1918 pp 72-7.

A comparison with some other Free Church schools is instructive: at Taunton of a thousand and four serving at least one hunded and sixty-five were killed; at Bishop's Stortford of nearly six hundred serving fifty-five died; at Tettenhall of over two hundred serving, twenty-four died; at Eltham College (for missionaries' sons) of one hundred and twenty serving, twenty-nine were killed; at Silcoates (for Congregational ministers' sons) two hundred were fighting by February 1917, and by 1919 forty-one had died; at Caterham (for Congregational ministers' sons) sixty-nine died. The respective sizes of the schools is not easy to determine. Of the three comparable schools Mill Hill topped three hundred by 1917; Taunton was larger; Bishop's Stortford smaller. Tettenhall had one hundred and thirty four boys by 1919; Eltham one hundred and sixty by 1919; Caterham had over two hundred by 1919; Silcoates was the smallest, varying between seventy-three and eighty-nine boys between 1914 and 1919. See S. P. Record, Proud Century: The First Hundred Years of Taunton School (Taunton 1948) p 175; J. Morley and N. Monk-Jones, Bishop's Stortford College, 1868-1968. A Centenary Chronicle (London 


\section{Et Virtutem Et Musas}

proposal of June 1916 to found scholarships for the sons of Old Millhillians killed in the war. ${ }^{125}$ By late 1918 there was a triple thrust to the memorial: the scholarship scheme; a memorial 'of artistic beauty'; and, since 'Science, whose developments have counted for so much in the War, should have greater facilities at Mill Hill for developments appropriate to the time of peace', laboratories and lecture rooms. The need was for $£ 25,000.126$ The memorial of artistic beauty, in the shape of a classical gate of honour, was opened by Lord Horne in October 1920.127 A memorial lectern designed by Basil Champneys followed in July 1921 and a Book of Remembrance and War Record, 'a model of all that such a book should be', in 1922. ${ }^{128}$ It was only in February 1924 that the reticently neo-Georgian science block could be opened, for it was only then that the prince of Wales, 'after two postponements made inevitable through accidents', could provide the school's first royal visit, a well briefed affair, with the tactful royal recollection that he and the headmaster were undergraduates at Oxford together (cheers). ${ }^{29}$

This headmaster was not McClure but Maurice Jacks, an Oxford newcomer, for McClure, who was a Cambridge man, had died suddenly two years before, the magazine's insertion sufficient memorial: 'I have written no books and I shall write none; you are my books'. ${ }^{130}$

The school's return to normalcy with first peace and then a new headmaster to be learned was not always smooth. Numbers slipped. 131 The political background was not to be disregarded. The first peace time editorial focused on the drawbacks of the public school system with a quotation 'from the pen of Labour'. Its conclusion misfired: 'Let us start a movement for the Redecoration of the Public Schools on simple yet artistic lines'. ${ }^{132}$ In March 1919

1969) p 55; The Tettenhallian. College Centenary Vol xxxiv June 1963 No $3 p$ 126; The Glory of the Sons p 74; H. H. Oakley. The First Century of Silcoates (Cheltenham 1920) p 56; H. Stafford, A History of Caterham (Shrewsbury 1945) p 100.

125 MHM June 1916 pp 5-6.

126 Ibid December 1918 pp 88-9.

127 Ibid December 1920 pp 108-9.

128 Ibid July 1921 pp 22-3; June 1922 p 23.

129 Ibid April 1924 pp 242-5.

130 Ibid March 1922 facing $p 89$.

131 to 283 in June 1922; ibid June 1922 p 23.

132 Ibid December 1918 pp 65-6. 
it was the turn of George Lansbury, pleading for tolerance, 'the mental quality of suffering with and respecting the opinions . . . of others'. This time the conclusion was the duchess's remark to Alice that "'tis love, that makes the world go round'. And Lansbury himself came that month to lecture on 'Reconstruction' in the music schools, a 'unique opportunity', as the headmaster observed, to put 'ourselves in the position of the working-class man . . '133 In July it was 'The League of Nations and the School', which meant religious training as the international keynote, and the importance of teaching modern (that is to say, 1815 to 1915 ) history. ${ }^{134}$ And in that month W. L. Hichens spoke on industry and morality. Again McClure chaired, and the magazine's commentator wrote critically of one of Hichens's answers to questioning that 'to provide a thorough education for the working classes is a burden which the country in its present financial exhaustion cannot possibly bear.' 135 In November the debating society decided that Lloyd George was incapable of governing the country and in early 1920 it contemplated a programme of debates which justified Sinn Fein, argued that Labour (like Lloyd George) was unfit to govern, that governmental inefficiency was directly due to public school education and that Drinkwater's Abraham Lincoln was the greatest play since Shakespeare. ${ }^{136}$

But the casualties of war continued. There was news from an Old Boy whose war had been spent in Vienna ("It is a terrible experience to be on the losing side'); of another killed in Russia; of Herbert Ward, Old Boy par excellence, miner, sail-maker, seaman, stockrider, circus gymnast turned explorer, fashionable sculptor, expatriate Frenchman, friend of Lord Northcliffe, advocate of allied friendship, author of Mr. Poilu. ${ }^{137} \mathrm{~W}$ ar stories still featured, with 'An Incident of '15' about German murderousness in a prisoner of war camp, as the most savage of them all. 138 War books were still given to the library. But it was jazz that was now conquering:

133 Ibid March 1919 pp 99-100; April 1919 pp 153-5.

134 Ibid July 1919 pp 37-9.

135 Ibid $\mathrm{pp}$ 58-60.

136 Ibid December 1919 pp 155-6; March 1920 pp 205-6: Sinn Fein was justified by twenty five votes to ten, 'the most exciting debate of the session'.

137 'Tidings from Vienna' ibid June 1919 pp 17-18; November 1919 p 110-12, and N. G. B. J(ames) 'Mr. Poilu' ibid March 1917 pp 134-6.

138 Ibid April 1919 pp 155-8. 


\section{Et Virtutem Et Musas}

'Will you walk a little faster', said the prefect to the lad; 'There's a monitor behind me and he's jazzing it like mad;'

'You can really have no notion how delightful it will be When they take us up and whirl us, with the fellows, after tea.' 139

This was on a par with 'Enthusiasm and House Spirit,' the most philistinely sporting editorial for years: ' . . Before you is peace. The traditions that you set now will be the ruin or salvation of schoolboys (and through them of your country) for the next fifty years' ${ }^{140}$ The Oxford and Cambridge Letters returned, joined by one from Glasgow; and soldiers' tales from afar gave way, in the new, Smuts-coined consciousness of Commonwealth, to pieces on Australia and tea-planting in Assam and wireless. The wireless club, whose activities later reached the prince of Wales, by June 1921 had heard concerts 'from the Hague, from Berlin, and from Croydon; and voices from the cross channel aeroplane. ${ }^{141}$

Did any room remain for protestant dissent among such enlarged horizons? Certainly the early post war issues printed more overtly 'churchy' pieces than had been the magazine's normal custom. When P.C.H. contributed 'Ad Saecula Saeculorum' as an understanding of Roman Catholicism (In claiming the liberty of Christ, we too often forget the fear of God. That is what we may learn from the Church of St. Peter'), an Old Millhillian responded fiercely from Spain with 'For Ever and Ever', a condemnation of Spanish Catholicism. ${ }^{142}$ The exchange embarrassed the editor. The Free Church schools were now at the point, already foreshadowed in this paper, where Free Churchmanship must be a minority commitment in class and staff room alike, reflected only in the flavour of chapel, the composition of governing bodies, the scattered presence of manse sons. At the very point at which they had tested their membership of the public school community and then of the national community, they were slipping both from their own immediate hinterland and from what was to be the mainstream of the

139 Ibid March 1919 p 121.

140 Ibid June 1919 pp 1-3.

141 'Australian Types' ibid pp 9-11; 'Australia and Peace' July 1919 pp 54-5; 'Tea-Planting in Assam' November 1920 pp 81-6; December 1920 pp 111-3; June 1921 pp 15-16.

142 Ibid November 1919 pp 112-4; March 1922 pp 181-3. 
educational future, although it would take the second world war, whose aftermath saw them at their most prosperous, to make that clear.

Yet in 1919 they were still intimately connected with the Free Church leadership. In that year, for example, the chairman of the Congregational union was Mill Hill's headmaster, Sir John McClure; the president of the Baptist union was one of its best known Old Boys, Herbert Marnham; and the moderator of the Presbyterian church of England, Alexander Ramsay, was the father of another. ${ }^{143}$ Three years later, 14 May 1922, McClure's successor, the twenty eight year old Maurice Jacks, preached his first sermon in Mill Hill school chapel. The magazine printed it in full:

religion does more than face the crises which are already there-it creates new crises; it does more than help us in our old perplexities-it gives birth to new perplexities; it does more than show us which way to choose in embarrassing positions-it makes more positions embarrassing. ${ }^{144}$

That was in all respects a sermon for the 1920 s, its persuasively non-evangelical rhetoric inconceivable without the shared experience of total war, even at schoolboy remove. 'It is the duty of every Christian man to regard his religion as the Expeditionary Force of his soul'. ${ }^{145}$

University of Sheffield

143 Ibid June 1919 p 5.

144 'Sunday, May 14th, 1922' ibid June 1922 pp 4-9 especially $p$ 7.

145 Ibid p 6. 